\title{
Striated Duct
}

National Cancer Institute

\section{Source}

National Cancer Institute. Striated Duct. NCI Thesaurus. Code C33635.

A type of intralobular duct, which is found in some salivary glands, and which is lined by low columnar epithelial cells that have characteristic basal striations, which are formed by regions of basal membrane invaginations with mitochondrial accumulation. 